\title{
Trichoderma Genome to Genomics: A Review
}

Mukesh Srivastava*, Mohammad Shahid, Sonika Pandey, Anuradha Singh, Vipul Kumar, Shyamji Gupta and Manoj Maurya

Biocontrol Laboratory, Department of Plant Pathology, Chandra Shekhar Azad University of Agriculture \& Technology, Kanpur, Uttar Pradesh, India

\begin{abstract}
Trichoderma species are widely used in agriculture as biopesticides. These fungi reproduce asexually by production of conidia and chlamydospores and in wild habitats by ascospores. Trichoderma species are well known for their production of enzymes called Cell Wall Degrading Enzymes (CWDEs). All living organisms are made up of genes that code for a protein which performs the particular function. Some genes that play an important role in the biocontrol process are known as the biocontrol genes. These genes send some signals which help in secretion of proteins and enzymes that degrade the plant pathogens. These biocontrol genes can be cloned in huge amounts and can be used on large scale for commercial production. Some Trichoderma genes are also helpful in providing resistance to the biotic and abiotic stresses such as heat, drought and salt .The major biocontrol processes include antibiosis, mycoparasitism and providing plant nutrition.
\end{abstract}

Keywords: Trichoderma; Biocontrol genes; Cell wall degrading enzymes

Abbrevations: ITS: Internal Transcribed Spacer; GOLD: Genome Online Database; ISTH: International Sub-commission on Trichoderma and Hypocrea Taxonomy; ICTF: International Commission on the Taxonomy of Fungi; CWDEs: Cell Wall Degrading Enzymes

\section{Introduction}

The genus Trichoderma is commonly found in soils and on decaying wood and vegetable matter. Strains of Trichoderma are rarely associated with diseases of living plants, although an aggressive strains of Trichoderma causes a significant disease of the commercial mushroom and soil borne pathogens. Samuels [1] provides a comprehensive review of the biology of Trichoderma, and of the technological exploitation of Trichoderma species for enzyme production and biological control. In Trichoderma species sexual reproduction is not present and are believed to be mitotic and clonal. The nomenclature of these fungi is complicated because of their pleiomorphism -that is, some of them can exist in two morphologically and physiologically different stages. The sexual (teleomorphic) stage is known by the generic name Hypocrea, whereas the asexual (anamorphic or mitosporic) stage is called Trichoderma; here, we refer to the genus collectively as Hypocrea/Trichoderma. However, despite these significant advances in our knowledge of the genus, the taxonomy of Trichoderma is still incomplete, and the distinction of species in the genus Trichoderma remains problematic. A refined classification and identification is necessary for predictive indications about ecology.

\section{Taxonomic history}

Although the genus Trichoderma has been known since $19^{\text {th }}$ century. Its association with teleomorphs in Hypocrea Fr. was recognized by the Tulasne brothers in 1865, its taxonomy has remained obscure until recent decades. Bisby [2] thought that the morphological variation could be ascribed to a single species, $T$. viride. The first serious attempt to morphologically distinguish species, or "species aggregates", was made by Rifai [3], who was aware that the nine taxa he distinguished were not biological entities correlated with single teleomorph species. These and a few additional species described subsequently were keyed out by Domsch et al. [4]. Teleomorph connections were established by means of ascospore isolates by Dingley [5], and by Webster and coworkers (Rifai and Webster, Webster and Rifai). In Japan, a wealth of teleomorphs was studied thoroughly and described with cultural and anamorph characters by Doi [6-7], but unfortunately no cultures have been preserved from this study. No further morphological differentiation of the anamorphs was attempted by Doi and Doi. The most detailed morphological studies of the anamorphs were carried out by Bissett [8-12], who now distinguishes about 21 taxa in sect. Pachybasium and seven in sect. Longibrachiatum, while the remaining sections have not yet been treated in a comparable way. Such studies show that the delimitation of biological species is extremely difficult in this genus on morphological grounds alone.

Other taxonomic methods supplementary to morphology include studies of secondary metabolites, which show a great diversity in this genus [13]. Physiological features detectable in microtiter plates may eventually provide a useful system for identification. Isoenzyme profiles have been used as an effective taxonomic tool [14]. Molecular data, particularly sequences of the ITS region of ribosomal DNA and fingerprinting techniques, have in recent years allowed the finest resolution of taxonomic entitiesn [15-17].

\section{Trichoderma genetics}

The genome size of filamentous fungi is usually small. They have a haploid nucleus. The estimated genome sizes and chromosome numbers of Trichoderma spp. range from 31 to $39 \mathrm{Mb}$ and from 3 to 7 , respectively. The size of chromosome differs among the species. International meetings devoted to Trichoderma are organising in whole world. In October 2010 a ARD (US-Israel Binational Research and Development Fund) workshop, 'Molecular mechanisms and applications of biocontrol in agriculture', was held at the Technion, Israel Institute of Technology, Haifa, Israel. This workshop was organised after the release of the sequenced genomes of T. atroviride and T. virens, which, together with $T$. reesei, gave novel insight into the evolution of mycoparasitism [18-26].

*Corresponding author: Srivastava M, Principal Investigator NAE, Department of Plant Pathology, C.S Azad University of Agriculture and Technology, Kanpur, UP India, Tel: 098-3981-8899; E-mail: biocontrol.csa@gmail.com

Received August 07, 2014; Accepted October 04, 2014; Published October 06 2014

Citation: Srivastava M, Shahid M, Pandey S, Singh A, Kumar V, et al. (2014) Trichoderma Genome to Genomics: A Review. J Data Mining Genomics Proteomics 5: 162. doi:10.4172/2153-0602.1000162

Copyright: (c) 2014 Srivastava M, et al. This is an open-access article distributed under the terms of the Creative Commons Attribution License, which permits unrestricted use, distribution, and reproduction in any medium, provided the original author and source are credited. 


\section{Genomics of Trichoderma}

Among different species of Trichoderma Treesei is the species whose genome is completely sequenced. From industrial point of view this strain is very important, as this strain has a large capacity to produce cellulose and hemicelluloses enzymes. Genome size of T. reesei is $33 \mathrm{Mb}$ and it has seven chromosomes. Apart from T.reesei there are some other species whose genome is sequenced completely and specific characters of their sequenced genomes are listed below:

Genomic analysis of the important genes/nucleotides involved in biocontrol mechanism in Trichoderma spp. by bioinformatics tools

ISTH (International Sub-commission on Trichoderma and Hypocrea Taxonomy), a Sub-commission of ICTF (International Commission on the Taxonomy of Fungi), hosts an online method for the quick molecular identification of Hypocrea/Trichoderma species based on an oligonucleotide barcode: a diagnostic combination of several oligonucleotides (hallmarks) specifically allocated within the Internal Transcribed Spacer 1 and 2 (ITS1 and 2) sequences of rDNA repeat. It helps in identifying specific strains of Trichoderma by comparing the sequence with the database by locating Genus Specific Hallmarks (GSH).

Once the strains are isolated in wet lab and their morphology is studied based on which the strain identification is done, the identification of isolated strains is done and validated at the ISTH website. As ISTH is solely dedicated for the identification of different strains of Trichoderma and Hypocrea species based on ITS sequences and other taxonomical data, the strains under study in this project are also validated through ISTH database.

The nucleotide sequences (submitted and retrieved from NCBI) of all seven strains of Trichoderma species are analyzed through TrichOKEY 2 program for their validation post molecular identification. This has confirmed the selected sequences as specific strains of Trichoderma species. A set of 5 oligonucleotide sequences which are present in all known Hypocrea/Trichoderma ITS1 - 5.8S RNA - ITS2 sequences, is used in combinations to identify the species at generic level.

TrichoMARK v. 1.0 is used for the detection of multiloci phylogenetic markers. It detects the presence of Internal Transcribed Spacer (ITS) regions in the entered sequences.

\begin{tabular}{|c|c|c|c|c|c|c|c|c|}
\hline \multicolumn{2}{|c|}{ Features } & T. reesei & T. virens & T. atroviride & T. harzianum & T. asperellum & T. longibrachiatum & T. ctrinoviride \\
\hline \multicolumn{2}{|c|}{ Genome size $(\mathrm{Mb})$} & 34.1 & 39 & 36.1 & 40.98 & 37.46 & 32.24 & 33.48 \\
\hline \multicolumn{2}{|c|}{ No of predicted genes } & 9129 & 12427 & 11863 & 14095 & 12566 & 10792 & 9397 \\
\hline \multirow{2}{*}{ Glycosyl hydrolases } & Chitinases & 23 & 41 & 34 & NA & NA & NA & NA \\
\hline & Glucanase & 15 & 18 & 18 & NA & NA & NA & NA \\
\hline \multicolumn{2}{|c|}{$\begin{array}{c}\text { Secondary metabolites Biosysnthesis, transport } \\
\text { and catabolisms (KOG) }\end{array}$} & 262 & 440 & 349 & 438 & 358 & 253 & 285 \\
\hline \multicolumn{2}{|c|}{ PKS } & 11 & 18 & 18 & NA & NA & NA & NA \\
\hline \multicolumn{2}{|c|}{ NRPS } & 10 & 28 & 16 & NA & NA & NA & NA \\
\hline \multicolumn{2}{|c|}{ PKS-NRPS } & 2 & 4 & 1 & NA & NA & NA & NA \\
\hline \multicolumn{2}{|c|}{ SSCPs } & 260 & 319 & 301 & NA & NA & NA & NA \\
\hline \multicolumn{2}{|c|}{$\begin{array}{l}\text { Xenobiotics bidegradation and metabolisms } \\
\text { (KEGG) }\end{array}$} & 327 & 519 & 453 & 610 & 432 & 232 & 359 \\
\hline \multicolumn{2}{|c|}{ Mating types } & MAT1-2 & MAT1-2 & MAT1-2 & MAT1-2 & MAT1 & MAT1-1 & MAT1-2 \\
\hline
\end{tabular}

Table 1: A summary of some features of the sequenced genomes.

\begin{tabular}{|c|c|c|}
\hline Name of gene & Source Organism & Function \\
\hline Tvsp1 & Trichoderma virens & $\begin{array}{l}\text { This gene encodes for serine protease. Rhizoctonia solani which affects the cotton seedlings has been } \\
\text { controlled biologically by serine protease. }\end{array}$ \\
\hline tri5 & Trichoderma harzianum & $\begin{array}{c}\text { This gene is responsible for the synthesis of the enzyme trichothecene which inhibits the protein and DNA } \\
\text { synthesis in the cells of the pathogens and inhibits their growth. }\end{array}$ \\
\hline $\operatorname{Tga} A$ and $\operatorname{TgaB}$ & Trichoderma virens, & This gene exhibits antagonist activity against $R$. solani and Sclerotium rolfsii \\
\hline ThPG1 & Trichoderma harzianum & $\begin{array}{c}\text { This gene encodes for endopoly- galacturonase. This enzyme involves in the cell wall degradation of the } \\
\text { pathogens like R. solani and P. ultimum }\end{array}$ \\
\hline Th-Chit & Trichoderma harzianum & This gene is responsible for the antifungal activity in transgenic tobacco plant. \\
\hline tri5 & Trichoderma brevicompactum & $\begin{array}{l}\text { This gene helps in the production of Trichodermin which shows antifungal activity against S. cerevisiae, } \\
\text { Kluyveromyces marxianus, Candida albicans, C. glabrata, C. tropicalis and Aspergillus fumigates. }\end{array}$ \\
\hline erg1 & Trichoderma harzianum & $\begin{array}{l}\text { This gene encodes an enzyme named squalene epoxidase, which helps in the synthesis of ergosterol and } \\
\text { silencing of this gene provides resistance to terbinafine, an antifungal compound. }\end{array}$ \\
\hline TVGST & Trichoderma virens & This gene is responsible for cadmium tolerance \\
\hline Thkel1 & Trichoderma harzianum & $\begin{array}{l}\text { This gene codes for putative kelch-repeat protein which helps in regulating the glucosidase activity and } \\
\text { enhances tolerance to salt and osmotic stresses in Arabidopsis thaliana plants }\end{array}$ \\
\hline egl1. & Trichoderma longibrachiatum & This gene showed biocontrol activity against $P$. ultimum in damping- off of cucumber \\
\hline qid74 & Trichoderma harzianum CECT 2413 & $\begin{array}{l}\text { This gene plays a significant role in cell protection and provide adherence to hydrophobic surfaces that helps } \\
\text { the fungus in mycoparasitic activity against } R \text {. solani pathogen }\end{array}$ \\
\hline Taabc2 & Trichoderma atroviride & $\begin{array}{l}\text { This gene has a significant role in ATP Binding Cassette (ABC) transporter in cell membrane pump that helps } \\
\text { in the mycoparasitic activity }\end{array}$ \\
\hline tac1 & Trichoderma virens & This gene has its role in mycoparasitic activity against $R$. solani and $P$. ultimum \\
\hline $\operatorname{TrCCD1}$ & Trichoderma reesei & $\begin{array}{l}\text { This gene involves in carotenoid metabolism that helps in the development of conidiospores and hyphal } \\
\text { growth in T. reesei }\end{array}$ \\
\hline
\end{tabular}

Table 2: List of biocontrol genes involved in Biocontrol Mechanisms. 


\section{Trichoderma Biocontrol genes and their function}

Trichoderma species are used as biocontrol agents in ai all over the world.This genera have several biocontrol genes that are involved in the biocontrol mechanisms of (Pratibha sharma et al. 2011). Some major kinds of genes that are involved in biocontrol action are protease, chitinase, glucanase, tubulins, cell adhesion proteins and stress tolernt genes. These genes are responsible for cell wall degradation, hyphal growth, stress tolerance and parasitic activity. For example chitinase is responsible for the breakdown of glycosidic bond, xylanase for hemicellulose etc.

Due to their biotechnological and biological importance the genome sequencing of fungal genomes is under process. About near 500 fungal genomes have been sequenced. The information of all the sequenced genomes is available on Genome Online Database GOLD (https://gold.jgi-psf.org/cgi-bin/GOLD/bin/gold.cgi). The Fungal Genome Initiative at the Broad Institute currently have around 50 fungal genomes, mainly from the Ascomycota, and includes model organisms such as Neurospora and Aspergillus species, but also extends to the genomes of several basidiomycetes, chytrids, and at least one mucormycete (http://www.broadinstitute.org/scientific-community/ science/projects/fungal-genome $\% 20$ initiative/fungal-genomeinitiative). The mycorrhizal genome initiative,designed to sequence and analyze the genomes of ascomycetes and basidiomycetes that function in symbiotic relationship with woody shurbs and trees. After compilation, this data will provide a framework for understanding the biology of these organisms and exploring their applications in reforestration and maintenance of ecological biodiversity. The fingla kingdom contributes for around more than $15 \%$ of species richness found in the major group of microorganisms. The genome analysis of the $28 \mathrm{~s}$ rRNA is the best used techniques for determining the fungal diversity.

\section{Conclusion}

Research data accumulated in the last few years have explore many new applications of fungal species into agriculture and biotechnology sector. These fungal species have the ability to change plant metabolism and provide resistance to abiotic and biotic stress. The genes present within the Trichoderma species have been found to have many biocontrol activities. This fungus secretes several cell wall degrading enzymes. These enzymes are used by transgenic plant cell to destroy phytopathogens. In an experiment performed by Liu et al. fungal cell wall degrading enzyme genes were isolated from the fungus Trichoderma atroviride and inserted into the rice genome via Agrobacterium-mediated transformation endochitinase ech42, exochitinase nag70 and exo-1,3-glucanase gluc78 were excised from Trichoderma atroviride and were used to prepared plasmids containing different combinations. Inoculation of the plants with $R$. solani resulted in a high sheath blight resistance rate in plants that received the ech 42 gene. Trichoderma species are all well known for their biocontrol properties in the whole world. This biocontrol activity is well known by the characterization and isolation of the specific genes which are involved in this mechanism. The phytopathogens cause a major loss in the agriculture sector. So, farmers use hazardous chemicals for the prevention of these phytopathogens. These chemical pesticides are very harmful for the environment as the leave harmful residues in the soil, affecting the soil fertility. By increasing the use of biocontrol agents this problem can be overcome. The genes isolated from these biocontrol agents found to play an important role in the biocontrol activity. With help of genetic engineering still more number of genes should be discovered for the benefit of future generation.

\section{Acknowledgement}

The authors are grateful for the financial support granted by the Indian Council of Agriculture Research (ICAR) Govt. of India under the Niche Area of Excellence on "Exploration and Exploitation of Trichoderma as an antagonist against soil borne pathogens" running in the Biocontrol Laboratory, Department of Plant Pathology, C.S.A. University of Agriculture and Technology, Kanpur, India.

\section{References}

1. Samuels GJ, Petrini O, Manguin S (1994) Morphological and macromolecular characterization of Hypocrea schweinitzii and its Trichoderma anamorph. Mycologia 86:421-435.

2. Bisby GR (1939) Trichoderma viride Pers. Ex fries and notes on Hypocrea Trans Br Mycol Soc. 23:149-168.

3. Rifai MA (1969) A revision of the genus Trichoderma. Mycol Pap 116:1-56

4. Domsch KH, Gams W, Anderson TH (1980) Compendium of Soil Fungi Vols 1 and 2. Academic Press, London.

5. Dingley JM (1957) Life history studies in the genus Hypocrea Fr. Trans R Soc N Z. 84: 689-693.

6. Doi Y (1969) The genus Hypocrea and its allies in Japan. Bull Natn Sci Mus Tokyo 12: 693-724

7. Doi Y (1972) Revision of the Hypocreales with cultural observations. IV. The genus Hypocrea and its allies in Japan. (2) Enumeration of the species. Bull Natn Sci Mus Tokyo 15:649-751.

8. Bissett J (1984)A revision of the genus Trichoderma: I. Section Longibrachiatum sect. nov. Can J Bot 62:924-931.

9. Bissett J (1991) A revision of the genus Trichoderma. II. Infrageneric classification. Can J Bot 69:2357-2372.

10. Bissett, J (1991) A revision of the genus Trichoderma. III. Section Pachybasium Can J Bot 69: 2373-2417.

11. Bissett, J (1991) A revision of the genus Trichoderma. IV. Additional notes on section Longibrachiatum. Can J Bot 69:2418-2420.

12. Bissett J (1992) Trichoderma atroviride. Can J Bot 70:639-64

13. Okuda T, Fujiwara A, Fujiwara M (1982) Correlation between species of Trichoderma and production patterns of isonitrile antibiotics. Agric Biol Chem 46: 1811-1822.

14. Leuchtmann A, Petrini O, Samuels GJ (1996) Isozyme subgroups in Trichoderma section Longibrachiatum. Mycologia 88:384-394.

15. Fujimori F, Okuda T (1994) Application of the random amplified polymorphic DNA using the polymerase chain reaction for efficient elimination of duplicate strains in microbial screening. I Fungi J Antibiot 47: 173-182.

16. Meyer W, Morawetz R, Börner T, Kubicek CP (1992) The use of DNA fingerprint analysis in the classification of some species of the Trichoderma aggregate. Curr Genet 21:27-30.

17. Muthumeenakshi S, Mills PR, Brown AE, Seaby DA (1994) Intraspecific molecular variation among Trichoderma harzianum isolates colonizing mushroom compost in the British Isles. Microbiol 140:769-777.

18. Kubicek CP, Herrera-Estrella A, Seidl-Seiboth V, Martinez DA, Druzhinina IS (2011) Comparative genome sequence analysis underscores mycoparasitism as the ancestral life style of Trichoderma. Genome Biol 12: R40.

19. Gilly JA, Sands JA (1991) Electrophoretic karyotype of Trichoderma reesei. Biotechnol Lett 13:477-482.

20. Harman GE, Howell CR, Viterbo A, Chet I, Lorito M (2004) Trichoderma species--opportunistic, avirulent plant symbionts. Nat Rev Microbiol 2: 43-56.

21. Hayes CK, Harman GE, Woo SL, Gullino ML, Lorito M (1993) Methods for electrophoretic karyotyping of filamentous fungi in the genus Trichoderma. Anal Biochem 209: 176-182.

22. Herrera-Estrella A, Goldman GH, van Montagu M, Geremia RA (1993) Electrophoretic karyotype and gene assignment to resolved chromosomes of Trichoderma spp. Mol Microbiol 7: 515-521.

23. Mäntylä AL, Rossi $\mathrm{KH}$, Vanhanen $\mathrm{SA}$, Penttilä $\mathrm{ME}$, Suominen $\mathrm{PL}$, et al (1992) Electrophoretic karyotyping of wild-type and mutant Trichoderma longibrachiatum (reesei) strains. Curr Genet 21: 471-477. 
Citation: Srivastava M, Shahid M, Pandey S, Singh A, Kumar V, et al. (2014) Trichoderma Genome to Genomics: A Review. J Data Mining Genomics Proteomics 5: 162. doi:10.4172/2153-0602.1000162

Page 4 of 4

24. Shahid M, Srivastava M, Pandey S, Singh A Kumar V et al. (2014). Biocontrol Mechanisms by Trichoderma Through Genomics and Proteomics Analysis: A Review: Afr J Microbiol Res 8: 3064-3069.

25. Sharma P, Kumar V, Ramesh R, Saravanan K, Deep S, et al. (2011) Biocontrol Genes from Trichoderma species: A Review. Afr J Biotechnol.10:19898-19907.
26. Srivastava M, Shahid M, Singh A, Kumar V, Pandey S, et al. (2014) To Develop Strain Specific Molecular Marker for Easy and Proper Identification of Fungal Species Based on Molecular Characters: A Review. J Mol Biomark Diagn 5:172. 